\title{
Parathyroid Hormone-Related Protein Contributes to Early Healing of Habu Snake Venom-Induced Glomerulonephritis in Mice
}

\author{
Mazène Hochane, ${ }^{* \dagger}$ Denis Raison, ${ }^{* \dagger}$ Catherine Coquard, ${ }^{* \dagger \ddagger}$ Claire Béraud, ${ }^{*}$ Sabrina Danilin, ${ }^{* \ddagger}$ Audrey Bethry, ${ }^{*}$ \\ Thierry Massfelder, ${ }^{\star \star \ddagger}$ and Mariette Barthelmebs* ${ }^{\star \star \ddagger}$
}

From the Cell Signalisation and Communication in Kidney and Prostate Cancer Team,* INSERM, UMR_S1113, Strasbourg; the Strasbourg University, ${ }^{\dagger}$ UMR_S1113, Strasbourg; and the Strasbourg Federation of Translational Medecine, ${ }^{\ddagger}$ UMR_S1113, Strasbourg, France

\author{
Accepted for publication \\ December 22, 2017. \\ Address correspondence to \\ Mariette Barthelmebs, Ph.D., \\ INSERM, UMR_S1113, \\ Equipe Signalisation et \\ Communication Cellulaires \\ dans le Cancer du rein et de la \\ prostate, Faculté de Médecine, \\ 11 rue Humann, F-67085 \\ Strasbourg, France. E-mail: \\ barthelm@unistra.fr.
}

\begin{abstract}
Proliferative glomerulonephritis is characterized by local inflammation and mesangial cell deterioration, followed by mesangial proliferation and glomerular healing. Parathyroid hormone-related peptide (PTHrP) is a mesangial cytokine-like growth factor implicated in mesangial proliferation and survival. No data are available about its role in glomerulonephritis. Herein, we analyzed the expression and role of PTHrP in glomerular inflammation and healing in an experimental model of glomerulonephritis induced by i.v. injection of Habu snake venom in mice. The temporal analysis showed marked renal damage in the first days after venom injection and the beginning of recovery within 7 days. Glomerular expression of PTHrP (transcript and protein) was observed in the early phase after venom injection (from day 1 to day 3), along with an inflammatory environment. The inactivation of secreted PTHrP with PTHrP-neutralizing antibody (PTH2E11; $120 \mu \mathrm{g}$ i.p. daily) reduced the markers of local inflammation (expression of macrophage chemotactic protein-1; regulated upon activation, normal $\mathrm{T}$ cell expressed and secreted; cyclooxygenase 2; IL-6; and macrophage infiltration) and abolished the expression of PTHrP itself. Moreover, the glomerular cell proliferation was hampered, and the healing process was prevented on day 7 after venom injection. These results show that PTHrP has antinomic actions in glomerulonephritis, participating in both the proinflammatory condition and the healing process. Our work reveals the essential role of PTHrP in early glomerular repair in an experimental model of glomerulonephritis. (Am J Pathol 2018, 188: 863-875; https://doi.org/10.1016/j.ajpath.2017.12.012)
\end{abstract}

The parathyroid hormone-related protein (PTHrP) is widely expressed in fetal and adult tissues, where it acts locally rather than in an endocrine manner. ${ }^{1,2}$ Through its $\mathrm{N}$-terminal PTH-like region, PTHrP binds and activates the PTH/PTHrP receptor. Cytosolic PTHrP can also use a bipartite multibasic nuclear localization signal to translocate to the nucleus and to act through an intracrine pathway. ${ }^{3}$ PTHrP has been described as a mitogenic and survival factor in many cell types through either of these pathways. $^{3-5}$

PTHrP is expressed in a constitutive manner in the kidney, although not in all kidney cell types in normal circumstances. It has been detected in the vascular and tubular compartments, where its physiological role is well documented. $^{6-9}$ Nonetheless, recent studies suggest a role of PTHrP in the progression of renal disease. Indeed, PTHrP was reported to be up-regulated in the renal cortex and expressed in the glomeruli in many experimental models of chronic renal insufficiency, after protein overload, after angiotensin II perfusion, or in diabetic nephropathy. ${ }^{10-12}$ In other studies, PTHrP appeared as an early immediate response factor in ischemic and toxic acute renal failure ${ }^{10,13}$ and as an actor in inflammatory processes. ${ }^{14} \mathrm{We}$ recently

\footnotetext{
Supported by INSERM, University of Strasbourg grants 2009 to 2014 (T.M.), and the French Ministry of Higher Education fellowship 2009 to 2012 (M.H.).

Disclosures: None declared.

Current address of M.H., Leiden Institute of Physics, Leiden, the Netherlands.
} 
reported distinct roles of PTHrP on the proliferation and apoptosis of mice mesangial cells in primary culture. PTHrP increased cell proliferation by acting through the intracrine pathway, whereas it enhanced cell survival by the paracrine pathway. ${ }^{15} \mathrm{We}$ also found that PTHrP is involved in the inflammatory process in mesangial cells. PTHrP expression was increased in cells treated by IL- $1 \beta$ or tumor necrosis factor- $\alpha$. A brief exposure of the cells to PTHrP itself was able to enhance the expression of IL$1 \beta$; IL-6; macrophage chemotactic protein-1 (MCP-1); regulated upon activation, normal $\mathrm{T}$ cell expressed and secreted (RANTES); and inducible cyclooxygenase 2 (Cox-2). ${ }^{16}$ However, the place of PTHrP in a pathologic condition involving mesangial cell proliferation and apoptosis, all in an inflammatory environment, has not yet been considered, and the role of PTHrP in proliferative glomerulonephritis was not described.

Proliferative glomerulonephritis is a glomerular disease involving injury principally of mesangial cells. It is characterized by local inflammation, with mesangial cell expansion. These features can be experimentally produced, in an accelerated manner, through the i.v. injection of Habu snake venom (HSV). ${ }^{17}$ HSV-induced acute glomerulonephritis was characterized by an initial capillary widening attributable to mesangiolysis and rupture of the capillary tuft. This led to compensatory mesangial cell proliferation and matrix accumulation, which, in turn, was followed by glomerular cell apoptosis and resolution of glomerular hypercellularity. ${ }^{18-20}$ Mesangial cell proliferation was maximal 5 to 7 days after venom injection, and full recovery had been observed within 1 to 3 weeks. ${ }^{20}$ Inflammation in the damaged glomeruli was supported by the presence of infiltrating polymorphonuclear cells and macrophages, ${ }^{20,21}$ together with the acute expression of MCP-1 and IL- $6 .{ }^{21}$ The local expression of several growth factors has been suggested to contribute to the healing process. Plateletderived growth factor (PDGF), a potent mitogenic factor for mesangial cells, was expressed early, whereas transforming growth factor- $\beta$, a mesangial antimitotic factor, was up-regulated later. ${ }^{19}$ In addition, the expression of vascular endothelial growth factor accompanied endothelial cell proliferation and capillary tuft healing. ${ }^{22,23}$

The objective of the current study was to examine whether PTHrP is another factor contributing to the healing process in the HSV-induced glomerulonephritis in mice. The temporal course of PTHrP expression was analyzed in the damaged glomeruli after HSV injection. Then, the contribution of secreted PTHrP on glomerular outcome was evaluated by treating mice with a PTHrP-neutralizing antibody, PTH2E11. An up-regulation of PTHrP expression was observed in the early phase of the pathology (day 1 to 3 ), and the glomerular recovery was followed over 7 days. Our results showed that inactivation of PTHrP interfered with glomerular cell proliferation and local inflammation and that it reduced the healing in progress on day 7 .

\section{Materials and Methods}

\section{Mice}

All animal care and experimental procedures complied with the local ethical committee (Ethics Committee in Animal Experimentation-35) and were approved by the French government under authorization AL/02/09/02/13.

Male C57BL/6 mice (aged 7 weeks) were obtained from Janvier Labs (Le Genest Saint Isle, France). They were housed in the animal facilities of the Medical School, in standard collective cages, under a 12-hour light-dark cycle, with free access to food (SAFE-AO4 diet; SAFE, Villemoisson-sur-Orge, France) and tap water. Mice were allowed to habituate for 1 week in the animal facility before being selected randomly and divided into groups. Mice received a numerical code throughout the experiments, and analyses were performed without prior knowledge of the treatments.

\section{Habu Snake Venom-Induced Glomerulonephritis}

Glomerulonephritis was induced in 8- or 9-week-old mice by a single i.v. injection $(2.5 \mathrm{mg} / \mathrm{mL}$ per $\mathrm{kg})$ of HSV from Trimeresurus flavoviridis (Latoxan, Valence, France). Control animals were saline injected. Injections were performed slowly (1 minute 30 seconds) into the jugular vein, under light anesthesia with ketamine $(60 \mathrm{mg} / \mathrm{kg}$, i.p.; Merial, Reims, France) and xylazine ( $8 \mathrm{mg} / \mathrm{kg}$, i.p.; Bayer Pharma, Loos, France). Wound was sutured (Sterisilk 4/0; Sterifil, Casablanca, Morocco), disinfected, and protected (Urgo Spray; Laboratoires Urgo, Chenôve, France). The mice were kept on a heating table until awakening. The dose of HSV $(2.5 \mathrm{mg} / \mathrm{kg})$ was selected in a preliminary study as the maximal sublethal dose that can be used in the mice by the i.v. jugular route.

In another preliminary study, the time course of the glomerulonephritis was evaluated by sacrificing the mice at 1,3 , and 7 days after venom injection ( $n=5$ per group) or saline injection (control; $n=3$ ). In some mice, under ketamine/xylazine anesthesia (100 and $10 \mathrm{mg} / \mathrm{kg}$ ), kidneys were saline perfused in situ $(1 \mathrm{~mL} /$ minute $)$ via the abdominal aorta until kidney bleaching. Renal material was then used for histologic examination. Half a kidney was fixed for 3 hours in 4\% paraformaldehyde $(\mathrm{pH} 7.4)$ and paraffin embedded. Unwashed kidneys (one control and two HSV treated for each time point) were also obtained for histologic examination.

To examine the contribution of secreted PTHrP in the time course of the glomerulonephritis, four groups of mice were compared (four-group study): control, HSV treated (HSV group), HSV treated receiving concomitant treatment with a neutralizing antibody for PTHrP (PTH2E11; $120 \mu \mathrm{g} /$ day, i.p., per mouse) (HSV-P group), or HSV treated receiving cotreatment with normal mouse $\operatorname{IgG}(120 \mu \mathrm{g}$ per day, i.p., per mouse; Jackson Immunoresearch Labs, West Grove, PA) (HSV-I group). The cotreatments (PTH2E11 
and $\operatorname{IgG}$ ) began on the day before venom injection. Mice from the control and HSV groups were given equivalent i.p. saline injections. The PTHrP-neutralizing antibody, PTH2E11, is a mouse monoclonal antibody generated against human PTHrP(34-53) (provided by Dr. Mustapha Oulad-Abdelghani, Institut de Génétique et Biologie Moléculaire et Cellulaire: IGBMC, Illkirch, France) that cross-reacts with mouse PTHrP. We previously reported PTHrP immunostaining with PTH2E11 on mesangial cells in primary culture, which was absent from PTHrP-excised cells. ${ }^{15}$ Mice were sacrificed again at 1,3 , and 7 days after HSV injection. For each time point, a total of nearly 60 mice were included (Figure 1, A and B). Basal experiment was, therefore, duplicated on 2 following days, and finally completed by an additional experiment because HSV (2.5 $\mathrm{mg} / \mathrm{kg}$ ) elicited herein approximately $30 \%$ mortality in all HSV-treated groups (Figure 1C). Unwashed kidneys (half a kidney) were used for histologic analysis (macrophage infiltration), and the remaining material was used for the extraction of glomeruli by a sieving process, as described previously. ${ }^{15}$ Glomeruli were kept at $-80^{\circ} \mathrm{C}$ until use for RNA extraction. Washed kidneys were used for quantitative evaluation of the glomerular damage [hematoxylin and eosin (H\&E) staining] or of glomerular proliferating cells (Ki-67 staining). Finally, blood was withdrawn from the abdominal aorta before sacrifice, and plasma was stored at $-20^{\circ} \mathrm{C}$ until use. Creatinine levels were measured by an enzymatic method on an Olympus AU400 analyzer (Olympus SA, Rungis, France). ${ }^{24}$

\section{Histologic Examination}

Formalin-fixed, paraffin-embedded tissue sections $(6 \mu \mathrm{m}$ thick) were deparaffinized with toluene, followed by washing in isopropanol and water. To assess the morphologic changes in the kidneys, staining was performed with H\&E or Masson trichrome for light microscopic examination. For histopathological quantification, H\&E-stained washed kidneys were used for sequential examination of 50 cross sections of glomeruli. The total number of cells per glomerulus was normalized per glomerular area, and results are also given using a graded system (state 0 , normal; state $1,30 \%$ to $50 \%$ loss of cells; and state $2,>50 \%$ loss of cells).

\section{Quantification of Proliferating Glomerular Cells or Infiltrating Macrophages}

Immunohistochemical staining was performed to detect the glomerular expression of Ki-67 (proliferating cells) and F4/ 80 (macrophages). Indirect immunoperoxidase staining was performed with the following antibodies: polyclonal rabbit anti-Ki-67 antibody (1:200; ThermoFisher Scientific, Brebières, France), a marker of cellular proliferation; and polyclonal rabbit anti-mouse F4/80 antibody (1:200; Santa Cruz, Tebu-Bio, Le Perray-en Yvelines, France), which detects infiltrating macrophages. The kidney sections were dewaxed, rehydrated, and microwaved for 15 minutes in 10 $\mathrm{mmol} / \mathrm{L}$ sodium citrate buffer ( $\mathrm{pH}$ 6.0). The specimens were permeabilized $(0.5 \%$ Triton $\mathrm{X}-100)$ and incubated with blocking solution (1\% bovine serum albumin in phosphatebuffered saline; 30 minutes at room temperature), then with primary antibody (overnight at $4^{\circ} \mathrm{C}$ ), followed by biotinlabeled goat secondary anti-rabbit IgG (1:200; Vector Laboratories, Burlingame, CA; 1 hour at room temperature). After quenching of endogenous peroxidase activity $(0.5 \%$ $\mathrm{H}_{2} \mathrm{O}_{2}$ in methanol; 30 minutes at room temperature), the sections were stained by the standard avidin-biotinperoxidase complex technique (Vectastain Elite $\mathrm{ABC}$ kit; Vector Laboratories), using diaminobenzidine as chromogen (ImmPact DAB; Vector Laboratories) and hematoxylin for nuclei staining (only with Ki-67 staining). Image acquisition was performed using a Zeiss Axio-Imager Z2 microscope equipped with a Zeiss MRM B/W camera (magnification, $\times 650$; Carl Zeiss SAS, Marly le Roi, France). Immunostaining images were analyzed using ImageJ version 1.46r (NIH, Bethesda, MD; http://imagej. nih.gov/ij).

On each Ki-67-stained washed kidney sample, at least 50 cross sections of glomeruli were sequentially examined. The number of proliferating cells per glomerular cross section was determined $\left(\mathrm{Ki}-67^{+}\right.$cells) and expressed as percentage of
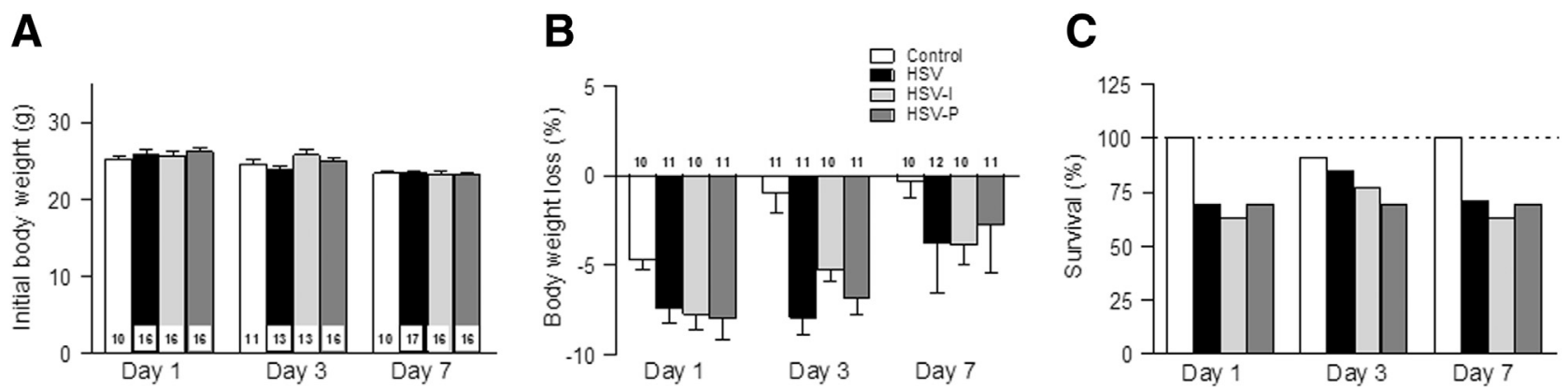

Figure 1 Description of the experimental groups (Materials and Methods). A: The mean initial body weight of the mice is similar in the different groups (the number of mice per group is indicated on each column). B: HSV treatment elicits a body weight loss (presented as percentage of the initial body weight) that is comparable within the three HSV-treated groups, whatever the day of sacrifice (the number of mice per group is indicated on each column). C: Some mice die early after HSV injection, but mortality (approximately 30\%) is in the same range within the three HSV-treated groups (dotted line represents $100 \%$ survival). Data are expressed as means $\pm \operatorname{SEM}(\mathbf{A}$ and $\mathbf{B})$. 
total glomerular cells. In a similar way, at least 30 cross sections of glomeruli per group were sequentially examined for F4/80 staining in unwashed kidneys. The number of infiltrating macrophages $\left(\mathrm{F} 4 / 80^{+}\right.$cells) was determined per glomerular cross section and normalized per glomerular area. To determine whether prohealing M2 macrophages were present, the level of arginase- 1 expression (a specific marker for M2 macrophages) was determined by RT-PCR.

\section{PTHrP Immunofluorescence}

Immunohistofluorescence staining was performed to detect PTHrP and $\alpha$-smooth muscle actin ( $\alpha$-SMA) on kidney slices. The kidney sections were similarly dewaxed, microwaved, permeabilized, and blocked for unspecific binding. The sections were then coincubated (overnight at $4^{\circ} \mathrm{C}$ ) with polyclonal rabbit anti-human PTHrP(24-35) antibody (1:600; C13 antiserum; a gift from Dr. Pedro Esbrit, Fundación Jiménez Díaz, Madrid, Spain) and monoclonal mouse antihuman $\alpha$-SMA antibody (1:50; Santa Cruz), followed by appropriate Alexa-conjugated goat IgG secondary antibodies (Life Technologies, Saint Aubin, France). Nuclei were stained by bisbenzimide H33342 (HOE 33342; Sigma-Aldrich, Saint Quentin Fallavier, France). As negative controls, primary antibodies were replaced by phosphate-buffered saline or the corresponding nonimmune serum (Millipore, Molsheim, France). We previously reported PTHrP immunostaining with C13 antiserum on mice aorta and intrarenal arteries, which markedly decreased after specific PTHrP knockdown in smooth muscle cells. ${ }^{8}$ Image acquisition (Zeiss Axio-Imager Z2 microscope, Zeiss MRM B/W camera) was performed as described above (Quantification of Proliferating Glomerular Cells or Infiltrating Macrophages).

\section{Apoptosis}

Apoptotic cells were detected on formalin-fixed, paraffinembedded kidney sections by the commercial in situ cell death detection kit (Roche Diagnostics, Meylan, France) based on the terminal deoxynucleotidyl transferase dUTP nick end labeling (TUNEL) technology. The kidney sections were dewaxed, rehydrated, microwaved for 15 minutes in 0.1 $\mathrm{mol} / \mathrm{L}$ sodium citrate buffer $(\mathrm{pH} 6.0)$, and permeabilized $(0.1 \%$ Triton $\mathrm{X}-100$ in $1 \%$ bovine serum albumin in phosphate-buffered saline; 8 minutes at room temperature) before being treated by the TUNEL reaction mixture ( 1 hour at $37^{\circ} \mathrm{C}$, in the dark), following the manufacturer's specifications. Nuclei were stained by bisbenzimide H33342 (HOE 33342). A negative control was performed by omitting terminal transferase from the TUNEL reaction mixture. A positive control was performed by incubating permeabilized cells with DNA I recombinase $(1000 \mathrm{U} / \mathrm{mL}$ of $50 \mathrm{mmol} / \mathrm{L}$ Tris $\mathrm{HCl}, \mathrm{pH} 7.5$, and $1 \mathrm{mg} / \mathrm{mL}$ bovine serum albumin) for 10 minutes at room temperature, before the labeling procedure. Image acquisition (Zeiss Axio-Imager Z2 microscope, Zeiss MRM B/W camera) was performed as described above (Quantification of Proliferating Glomerular Cells or Infiltrating Macrophages).

\section{Real-Time Quantitative RT-PCR Analysis}

Total RNA was extracted from the glomeruli using the RNeasy kit (Qiagen, Courtaboeuf, France). One microgram of total RNA was reverse transcribed using I-Script cDNA synthesis kit (BioRad, Marnes la Coquette, France). Quantitative realtime PCR was performed with the Light Cycler-FastStart DNA Master SYBR Green kit (Roche Diagnostics) to determine the expression levels of different transcripts. The following primer pairs were used: PTHrP, 5'-CAGCCGAAATCAGAGCTACC- $3^{\prime}$ (sense primer) and $5^{\prime}$-CTCCTGTTCTCTGCGTTTCC-3' (antisense primer); PTHrP receptor, 5'-GGGCACAAGAAGTGGATCAT-3' (sense primer) and $5^{\prime}$-GGCCATGAAGACGGTGTAGT-3' (antisense primer); PDGF-B, 5'-GGAGCACAGACTGGAGGAAC-3' (sense primer) and $5^{\prime}$-GTGGAGGAGCAGACTGGAGG-3' (antisense primer); vascular endothelial growth factor, 5'-CAGGCTGCTGTAACGATGAA- $3^{\prime}$ (sense primer) and $5^{\prime}$ GCATTCACATCTGCTGTGCT-3' (antisense primer); MCP1, 5'-TTCCTCCACCACCATGCAG-3' (sense primer) and $5^{\prime}$ CCAGCCGGCAACTGTGA-3' (antisense primer); RANTES, 5'-GACAGCACATGCATCTCCCA-3' (sense primer) and $5^{\prime}$-GTGTCCGAGCCATATGGTGA-3' (antisense primer); Cox-2, 5'-CCGTGCTGCTCTGTCTTAAC-3' (sense primer) and $5^{\prime}$-TTGGGAACCCTTCTTTGTTC-3' (antisense primer); IL-6, 5'-CCTACCCCAACTTCCAATGCTC- $3^{\prime}$ (sense primer) and $5^{\prime}$-TGGATGGTCTTGGTCCTTAGCC-3' (antisense primer); arginase-1, 5' TTTTAGGGTTACGGCCGGTG-3' (sense primer) and $5^{\prime}$ CCTCGAGGCTGTCCTTTTGA-3' (antisense primer); and 18S， 5'-CATGGCCGTTCTTAGTTGGT-3' (sense primer) and 5'-CGCTGAGCCAGTCAGTGTAG-3' (antisense primer). Each sample was analyzed three times and quantified with the analysis software for Light Cycler version 3.5 (Roche Diagnostics). Results are expressed as normalized ratios versus $18 S$ mRNA, the value of which is set at 1 for the control groups.

\section{Statistical Analysis}

Results are expressed as means \pm SEM. Statistical analysis was performed when appropriate using the Kruskal-Wallis test, followed by Dunn's multiple comparison test, or oneway analysis of variance, followed by Tukey's multiple comparison test. Post hoc tests were run only if $\mathrm{F}$ achieved $P<0.05$. Statistics were run with GraphPad Prism 5.00 (GraphPad Software, San Diego, CA).

\section{Results}

HSV Injection Induces Glomerulonephritis in Mice

The renal damage was observed immediately at the first day after the intrajugular venom injection (Figure 2A). The 
A

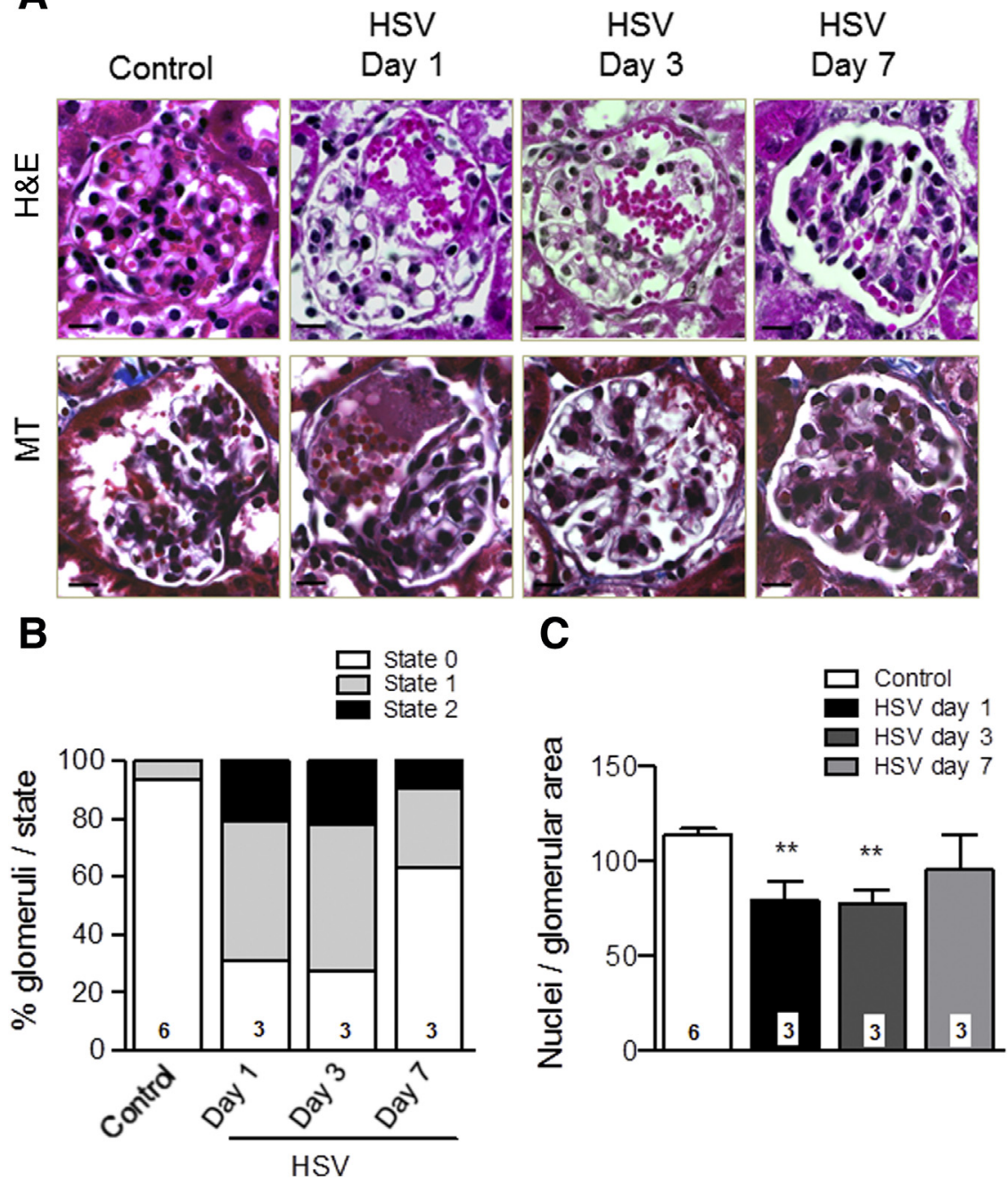

Figure 2 Time course of renal histologic changes after induction of glomerulonephritis by HSV in mice. A: Representative light micrographs of hematoxylin and eosin (H\&E) and Masson trichrome (MT) staining on unwashed kidneys. Because no changes occurred within the control groups during the 7-day follow-up, representative image is from day 1. B: Quantitative evaluation of the kinetics of the effects of HSV on glomerular damage determined in H\&E-stained washed kidneys. Results are expressed as percentage glomeruli in different states (state 0 , normal; state $1,30 \%$ to $50 \%$ loss of cells; and state $2,>50 \%$ loss of cells). C: The total cell number per glomerulus was determined in H\&E-stained washed kidneys and normalized per glomerular area ( $n$ is indicated for each group; the control group consisted of two mice from each time point). Statistical analysis by Kruskal-Wallis test, followed by Dunn's multiple comparison test. Data are expressed as means $\pm \mathrm{SEM}(\mathbf{C}) .{ }^{*} P<0.01$ versus control. Scale bars $=10 \mu \mathrm{m}(\mathbf{A})$. Original magnification, $\times 650$ (A). pathologic glomerular alterations agreed in general with previously published reports. ${ }^{19,20}$ Glomerular lesions were characterized by capillary dilatation and mesangiolytic ballooning during the acute phase (day 1 to 3 ). Microaneurysms filled with erythrocytes, neutrophils, and platelets are shown by H\&E or Masson trichrome staining (Figure 2A). This glomerular injury, clear at day 1 and day 3, largely decreased at day 7 after injection. No sign of fibrosis was seen even on day 7 after venom injection (Figure 2A). No notable histologic change occurred in control kidneys. When H\&E-stained slices (washed kidneys) were carefully analyzed, three principal observations were made: i) HSV injection induced an immediate damage in approximately $75 \%$ of glomeruli. ii) The loss of cells was variable among the damaged glomeruli and was distributed in three states. At day 1, 24\% of damaged glomeruli had lost $>50 \%$ of their cells (state 2), whereas only $10 \%$ of damaged glomeruli were in that state on day 7 (Figure 2B). iii) The overall analysis showed that the mean number of cells per glomerular area significantly decreased by one third and began to be restored within 1 week (Figure 2C).

\section{PTHrP Is Overexpressed Early in HSV-Induced Glomerulonephritis}

As expected, control kidneys display high PTHrP expression in tubular cells, but no staining was found in glomeruli, as shown by immune histofluorescence (Figure 3A). On day 1 after venom injection, remarkable PTHrP staining was observed in glomeruli. Weak staining persisted on day 3 but faded later on. Results from the preliminary study were confirmed in the four-group study. When activated, mesangial cells express markers of smooth muscle cells, like $\alpha$-SMA. Staining for $\alpha$-SMA was absent, as expected, in glomeruli from control mice (Figure $3 \mathrm{~A}$ ). Few $\alpha-\mathrm{SMA}^{+}$ cells were observed in damaged glomeruli 1 day after venom injection, although a larger number was seen on days 3 and 7. PTHrP expression was present in activated mesangial cells $\left(\alpha-\mathrm{SMA}^{+}\right.$cells $)$but also in all other 
A

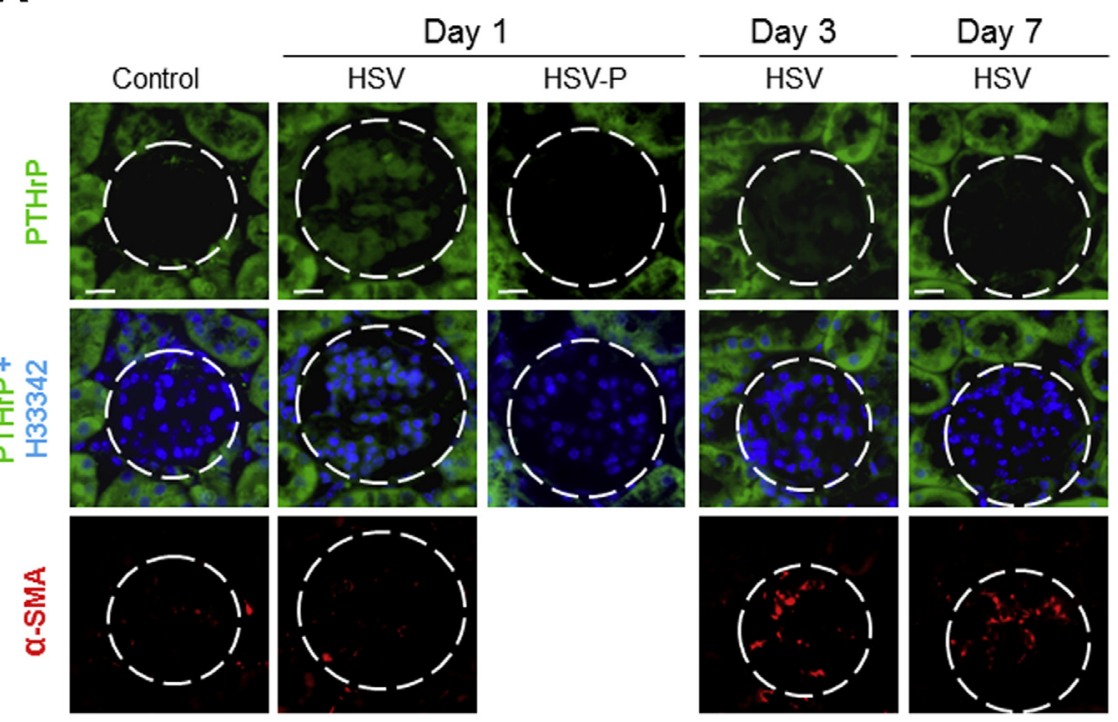

B

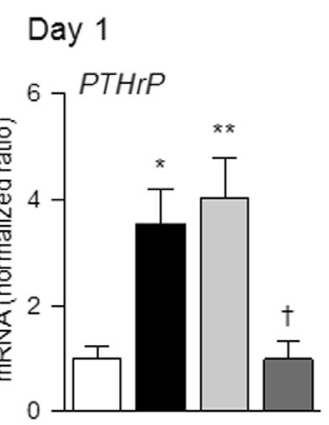

Day 1

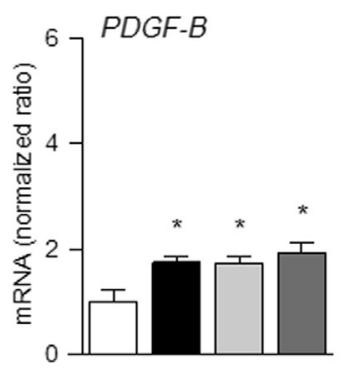

Day 3

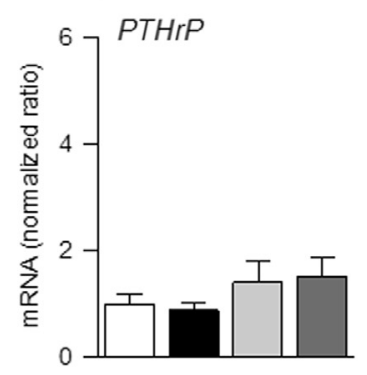

Day 7

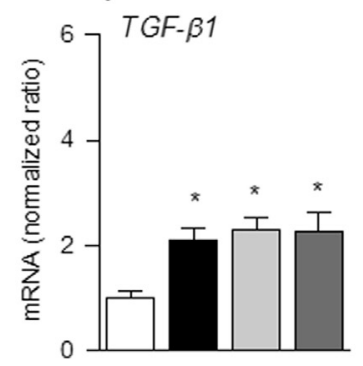

Figure 3 PTHrP expression in glomeruli during the development of HSV-induced glomerulonephritis in mice and effects of PTHrP-neutralizing antibody (PTH2E11). A: Triple immunohistofluorescence staining was performed on kidney slices from washed kidneys. The polyclonal rabbit anti-human PTHrP(24-35) antibody (C13 antiserum) was used for PTHrP immunostaining (green), and a monoclonal mouse anti-human $\alpha$ smooth muscle actin ( $\alpha$-SMA) antibody was used for $\alpha$-SMA detection (red). Nuclei (blue) were stained by bisbenzimide H33342. Dashed circles show the limits of glomeruli. B: PTHrP, PTH1R, $P D G F-B, V E G F$, and TGF- $\beta 1$ mRNA levels were determined on glomeruli isolated from mice from the four experimental groups (control, HSV, HSV-I, or HSV-P; Materials and Methods). The mRNA levels were expressed as a normalized ratio to 185 mRNA, and the value of the control group was set to 1 . Statistical analysis by analysis of variance, followed by Tukey's test. Data are expressed as means \pm SEM (B). $n=6$ per group (B). ${ }^{*} P<0.05,{ }^{*} P<0.01$ versus control; ${ }^{\dagger} P<0.05$ versus $\mathrm{HSV}$ on the corresponding day. Scale bars $=$ $10 \mu \mathrm{m}(\mathbf{A})$. Original magnification, $\times 650(\mathbf{A})$. PDGF, platelet-derived growth factor; PTH1R, PTHrP receptor; TGF- $\beta 1$, transforming growth factor- $\beta 1$; VEGF, vascular endothelial growth factor. glomerular cells, including probably podocytes and endothelial cells in the washed kidneys (Figure 3A).

The transient overexpression of PTHrP was confirmed at the transcript level on glomeruli isolated from venom-treated mice compared with control mice (Figure 3B). An increase in $\mathrm{PTHrP}$ mRNA level ( $3.55 \pm 0.65$-fold over control mice) was observed on day 1 after HSV injection, and the mRNA level went back to normal on day 3 . The same overexpression of PTHrP mRNA was found in IgG-treated mice (HSV-I group). However, PTHrP mRNA levels were brought to those of control glomeruli at day 1 after treatment of the mice with PTHrPneutralizing antibody (HSV-P group) (Figure 3B). This result is in line with the abolition of PTHrP immunofluorescence in the glomeruli from the same group at day 1 (Figure 3A). No change was seen in the mRNA level of PTHIR (Figure 3B). Among other growth factors previously shown to be enhanced in HSV-induced glomerulonephritis, ${ }^{19,23}$ an early increase in PDGF-B mRNA expression was observed, with a kinetic similar to that of PTHrP, although at a lower level, whereas no change in vascular endothelial growth factor expression was seen (Figure 3B). Treatment of the mice with PTHrP-neutralizing antibody had, however, no effect on $P D G F-B$ mRNA expression. A late (day 7) and moderate increase in $T G F-\beta 1 \mathrm{mRNA}$ also appeared insensitive to the treatment of mice with PTHrP-neutralizing antibody (Figure 3B). 
A

$\mathrm{F} 4 / 80^{+}$cells

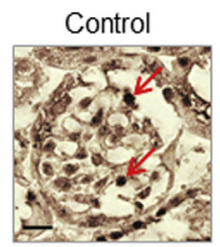

HSV

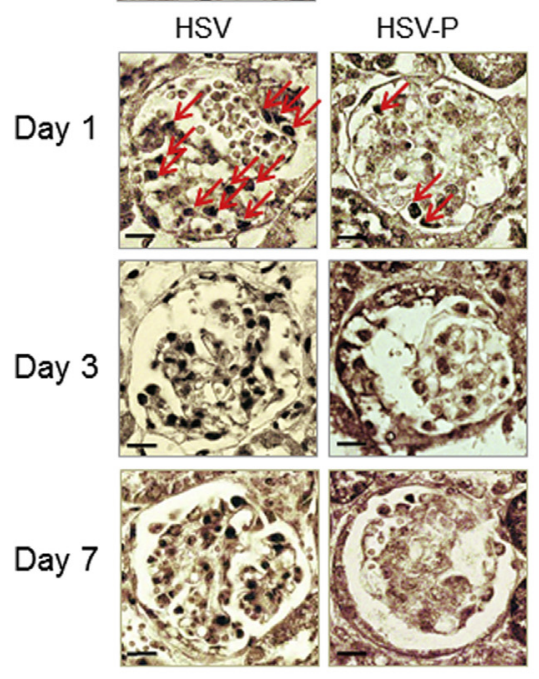

C

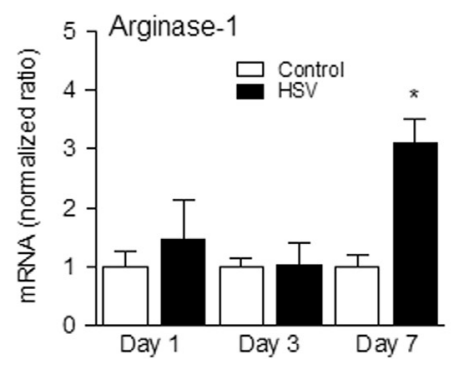

B
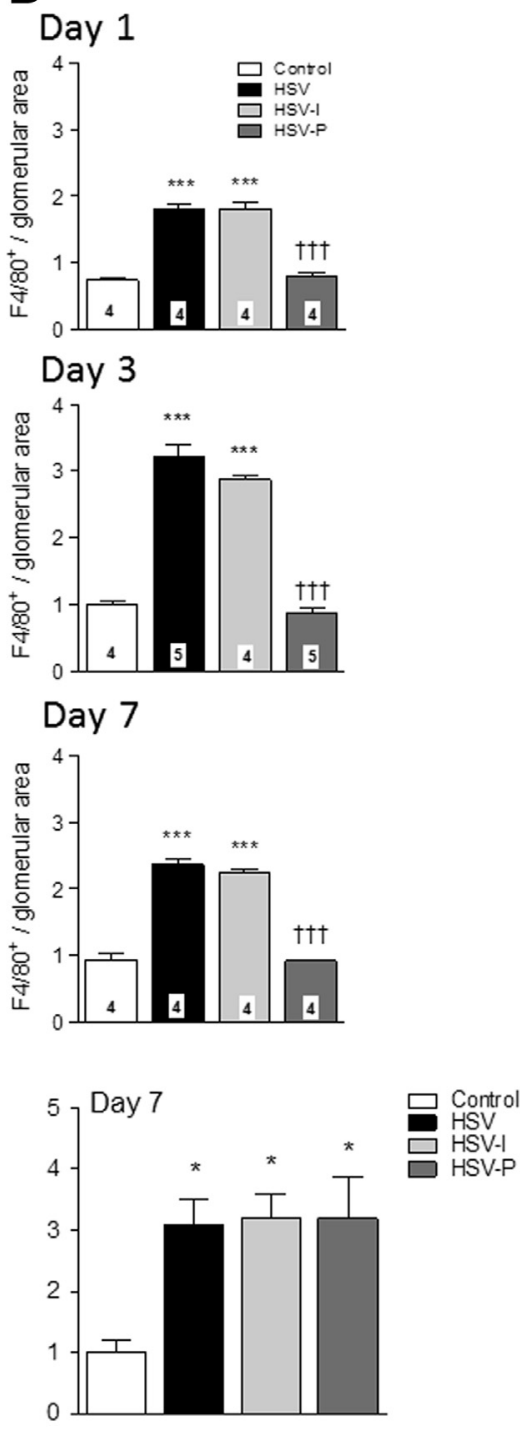

Figure 4 Effects of HSV and of PTHrPneutralizing antibody (PTH2E11) on the glomerular infiltration by macrophages in mice. A: Representative immunostaining of macrophages ( $\mathrm{F} 4 / 80^{+}$cells) on unwashed kidneys. Red arrows indicate some $\mathrm{F} 4 / 80^{+}$cells. B: The number of macrophages infiltrating glomeruli was determined on unwashed kidneys from the four experimental groups (control, HSV, HSV-I, or HSV-P; Materials and Methods). Results were normalized per glomerular area ( $n$ is indicated for each group). Statistical analysis by analysis of variance, followed by Tukey's test. C: Arginase-1 (marker of M2 macrophages) mRNA levels were determined on glomeruli isolated from mice from the different experimental groups (control, HSV, HSV-I, or HSV$P$ on day 1 , day 3 , or day 7 ). The mRNA levels were expressed as a normalized ratio to $18 \mathrm{~S} \mathrm{mRNA}$, and the value of the control group was set to 1 . Statistical analysis by $t$-test or analysis of variance, followed by Tukey's test. Data are expressed as means \pm SEM (B and C). $n=6$ per group (C). ${ }^{*} P<0.05,{ }^{* * *} P<0.001$ versus control on the corresponding day; ${ }^{\dagger \dagger} P<0.001$ versus HSV on the corresponding day. Scale bars $=10 \mu \mathrm{m}$ (A). Original magnification, $\times 650($ A).

\section{PTHrP Is an Actor of the Local Inflammatory Response}

To understand the role of PTHrP in glomerular inflammatory processes, the effects of PTHrP neutralization were analyzed by the PTH2E11 antibody on the glomerular inflammatory response elicited by HSV injection. HSV glomerulonephritis was accompanied by macrophage infiltration persistent from day 1 to day 7 , as shown via $\mathrm{F} 4 / 80^{+}$ cells (Figure 4A). The F4/80 ${ }^{+}$cells were, however, almost absent from the glomerular area in mice treated by the PTHrP-neutralizing antibody (HSV-P), all during the experiment from day 1 to day 7 (Figure 4B). The increase in arginase- 1 mRNA at day 7 signals the presence of M2 macrophages, which were insensitive to the treatment with PTHrP-neutralizing antibody (Figure 4C).

Furthermore, the expression of several cytokines/chemokines known to be involved in glomerular inflammation and to be induced by PTHrP in mesangial cells was analyzed. ${ }^{16}$ Results show that PTHrP promotes the inflammation in glomeruli. Indeed, the increase in RANTES, Cox-2, and IL-6 mRNA expression, which was observed on day 1 after HSV injection (HSV group), was almost abolished in mice concomitantly treated with the PTHrP-neutralizing antibody (HSV-P group) (Figure 5). The increase in MCP-1 expression was more prolonged, peaked at day 3 , and was only partially depressed in the HSV-P group. Treatment of the mice with normal mouse IgG (HSV-I group) had no effect.

\section{PTHrP Is Required for the Healing Process of HSV- Induced Glomerulonephritis}

The spontaneous healing observed in HSV-induced glomerulonephritis after approximately 1 week (preliminary study) was confirmed in the four-group study. Our 

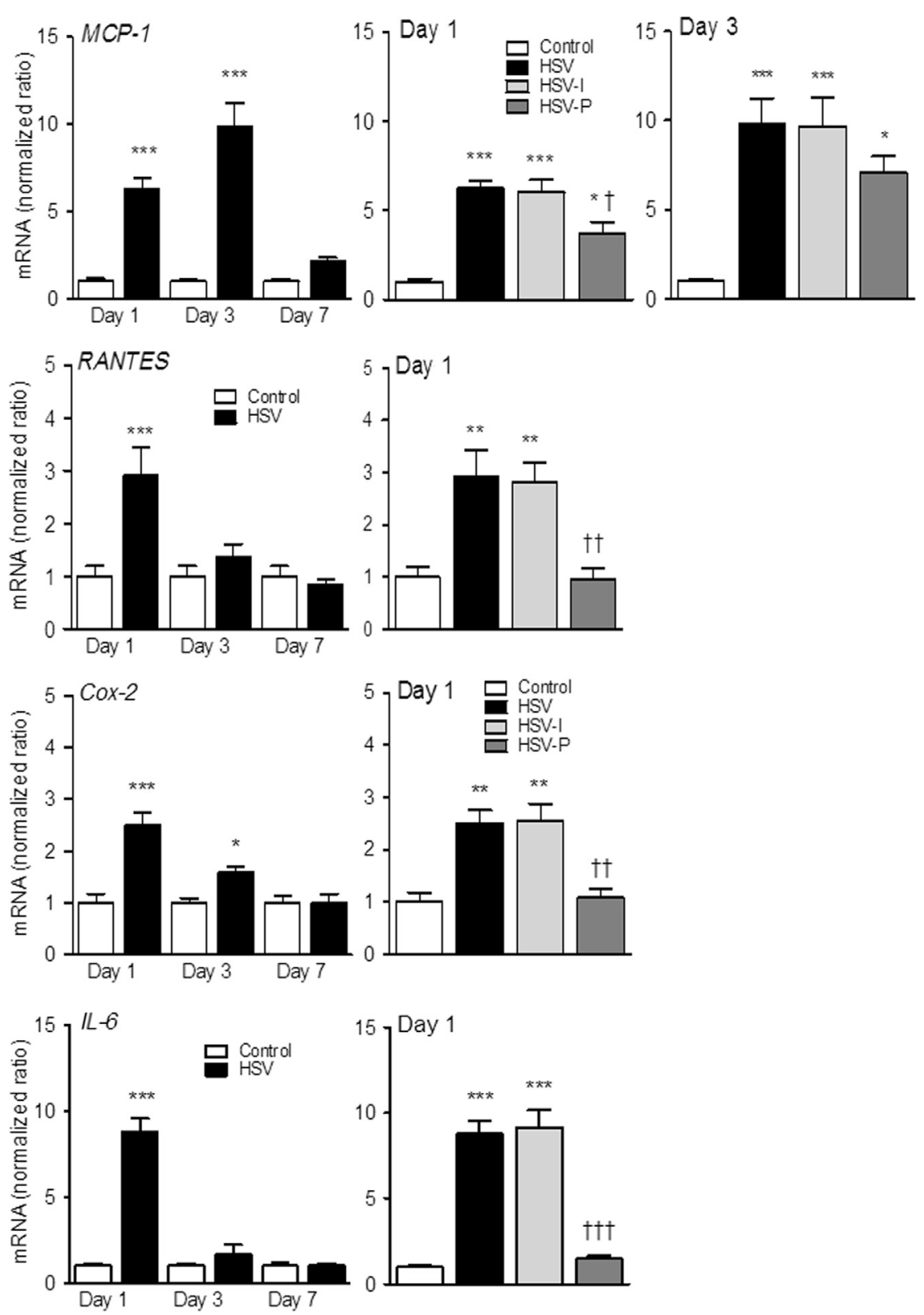

results showed the marked alteration in glomerular structure at day 1 after HSV injection and the beginning of spontaneous resolution on day 7 (Figure 6A). In addition, treatment with PTHrP-neutralizing antibodies hampered the spontaneous glomerular healing (Figure 6A). In fact, total nuclei count per glomerular area was decreased by one third on day 1 and 3 in all HSV-treated groups compared with control, and the damaged glomeruli were in similar states (Figure 6, B and C). However, at day 7, the number of nuclei/glomerular area was partially restored in the HSV and HSV-I groups (approximately 20\% decrease persisted), but not in mice treated with PTHrP-neutralizing antibodies, which showed glomerular morphology worsening (Figure 6A) and hypopopulated glomeruli (Figure 6B). In
Figure 5 Effects of HSV and of PTHrPneutralizing antibody (PTH2E11) on glomerular expression of inflammatory factors in mice. $M C P-1$, RANTES, Cox-2, and IL-6 mRNA levels were determined on glomeruli isolated from mice from the different experimental groups (control, HSV, HSVI, or HSV-P; Materials and Methods) on day 1, day 3, or day 7. The mRNA levels were expressed as a normalized ratio to $185 \mathrm{mRNA}$, and the value of the control group was set to 1 . Statistical analysis by $t$-test or analysis of variance, followed by Tukey's test. Data are expressed as means \pm SEM. $n=6$ per group. ${ }^{*} P<0.05,{ }^{*} P<0.01$, and $* * * P<0.001$ versus control; ${ }^{\dagger} P<0.05$, ${ }^{\dagger \dagger} P<0.01$, and ${ }^{\dagger \dagger} P<0.001$ versus HSV on the corresponding day. fact, $33 \%$ of glomeruli were still in state 2 with $>50 \%$ cell loss at day 7 after PTHrP neutralization (HSV-P) compared with only $5 \%$ to $10 \%$ glomeruli in HSV and HSV-I groups (Figure 6C). However, because only $30 \%$ of glomeruli were severely damaged in the HSV-P group even on day 7, plasma creatinine was not enhanced (Figure 7). Whatever the time considered, the HSV-I group never differed from the HSV group.

\section{PTHrP Contributes to Glomerular Cell Proliferation}

We have previously reported a role of intracrine PTHrP in mesangial cell proliferation. ${ }^{15}$ Because mesangial cell proliferation is crucial for the glomerular healing process, 
A

H\&E staining

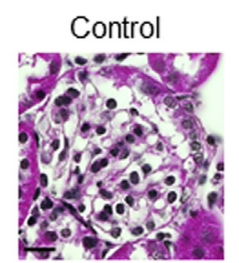

HSV

Day 1
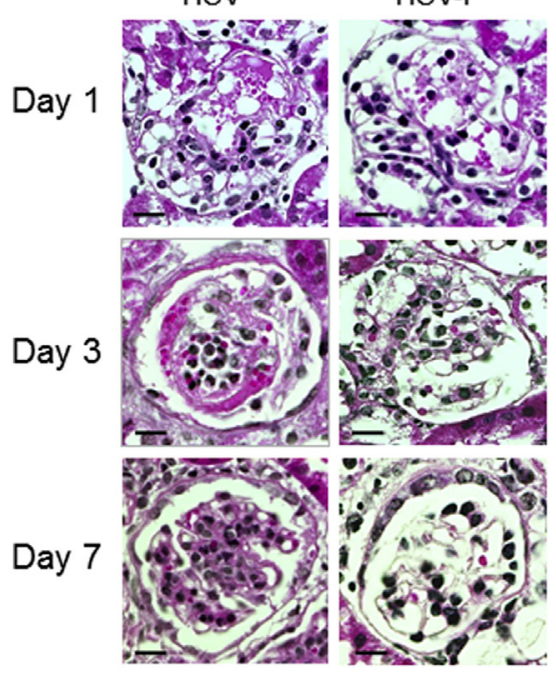

C

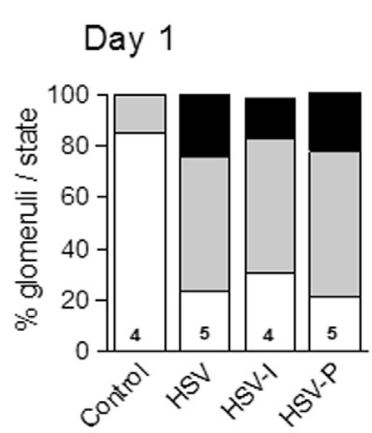

B
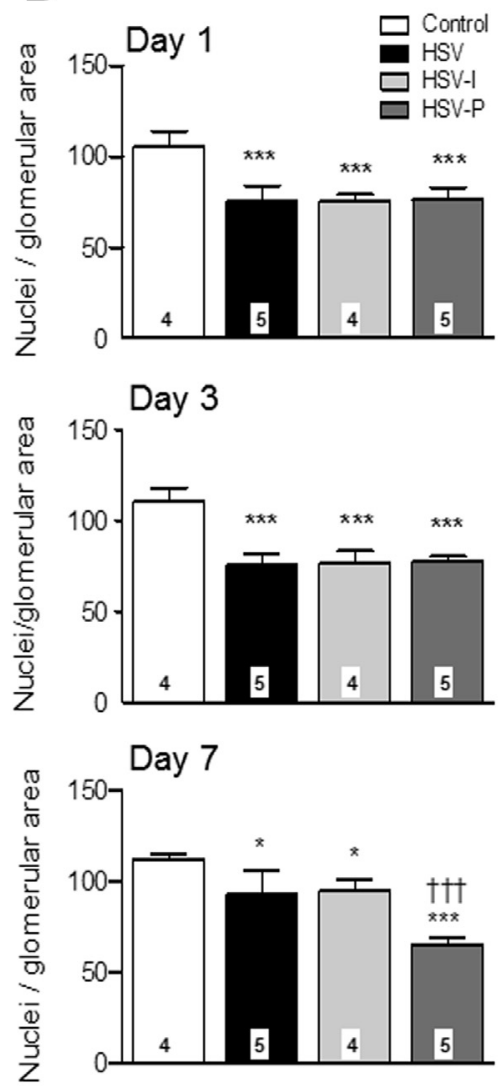

Figure 6 Effects of the PTHrP-neutralizing antibody (PTH2E11) on renal histologic changes in HSV-induced glomerulonephritis in mice. A: Representative light micrographs of hematoxylin \& eosin (H\&E) staining on washed kidneys. B: Quantitative evaluation of the glomerular damage was performed by counting the total cell number per glomerulus in H\&E-stained washed kidneys from the four experimental groups (control, HSV, HSV-I, or HSV-P; described in Materials and Methods). Results were normalized per glomerular area ( $n$ is indicated for each group). Statistical analysis by analysis of variance, followed by Tukey's test. C: Results are also expressed as percentage of glomeruli in different states (state 0 , normal; state $1,30 \%$ to $50 \%$ loss of cells; and state $2,>50 \%$ loss of cells). Data are expressed as means \pm SEM (B). ${ }^{*} P<0.05,{ }^{* * *} P<0.001$ versus control; ${ }^{\dagger \dagger} P<0.001$ versus HSV on the corresponding day. Scale bars $=10 \mu \mathrm{m}(\mathbf{A})$. Original magnification, $\times 650(\mathbf{A})$.

proliferating cells were evaluated in glomeruli by the Ki-67 staining (Figure 8A). Marked staining was observed in the HSV groups, whatever the time after venom injection, with up to $14 \%$ of glomerular cells being in proliferation at day 7 (Figure 8, A and B). A decrease in the proliferating glomerular cells was observed on day 1 in the HSV-P group, which persisted to some extent up to day 7 (Figure 8, A and B). Results in the HSV-I group were always similar to that in the HSV group. Together, these results indicate a prominent role of PTHrP in the healing process, mainly through a mitogenic action.

Because PTHrP was also shown to be a survival factor for mesangial cells, ${ }^{15}$ it was examined whether glomerular cell apoptosis occurs in this model of glomerulonephritis. The analysis of apoptosis by TUNEL staining showed that no apoptosis was observed in the glomerular compartment in HSV-induced glomerulonephritis (Figure 8C). Scarce apoptotic cells, however, appeared on day 7 in the HSV-P group (Figure 8C).

\section{Discussion}

HSV-induced nephropathy is a well-known model of mesangioproliferative glomerulonephritis with spontaneous resolution. ${ }^{18}$ The glomerular damage begins with 

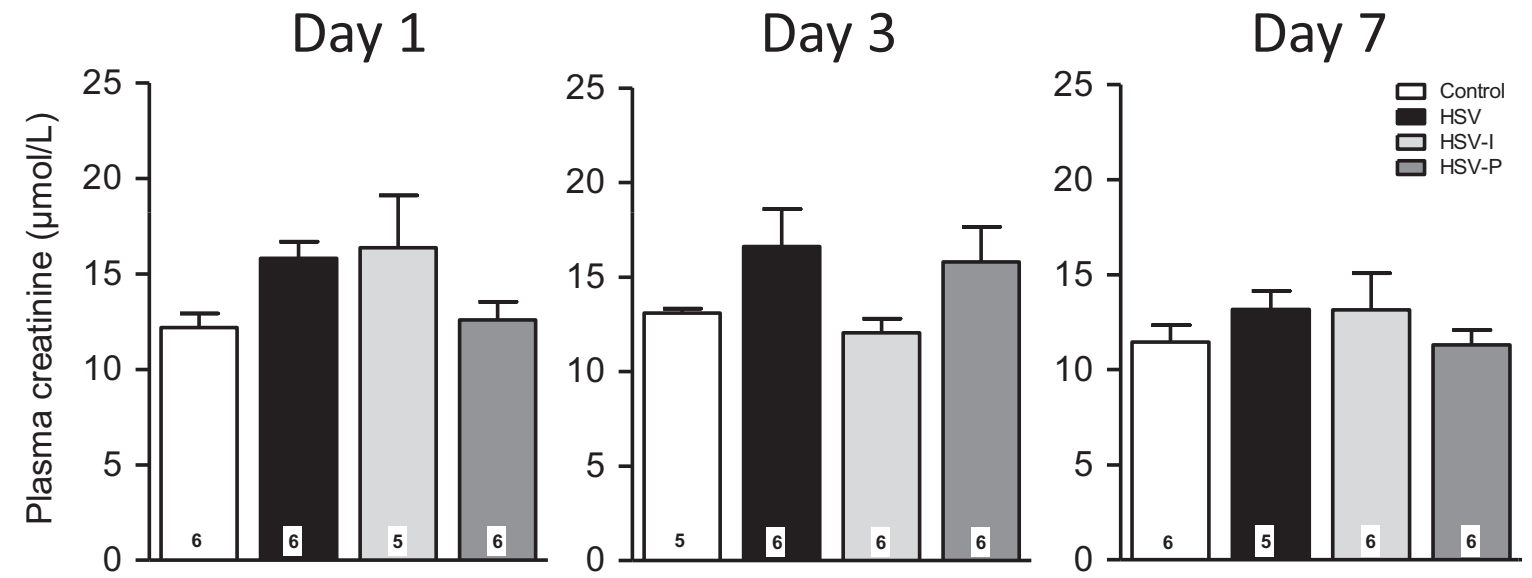

Figure 7 Effects of HSV on plasma creatinine levels measured 1, 3, and 7 days after venom injection. The number of mice per group is indicated on each column. Statistical analysis by analysis of variance is nonsignificant. Data are expressed as means $\pm \mathrm{SEM}$. All groups are described in Materials and Methods.

the dissolution of the mesangial matrix, attributable to the proteolytic activity of the venom, ${ }^{25}$ associated with the degeneration of mesangial cells. ${ }^{17,26}$ The venom is also rich in phospholipase A2, a key enzyme in the regulation of lipid mediators of inflammation. ${ }^{27}$ The inflammatory environment is further amplified with an enhanced expression of MCP-1 and infiltration of macrophages into the glomerular lesions. ${ }^{19-21,28}$ In the acute phase, impairment in mesangial integrity and loss of endothelial cells lead to ballooning of glomerular capillaries and microaneurysms filled with erythrocytes, neutrophils, and platelets. ${ }^{26}$ Spontaneous healing occurs later with mesangial cell migration and proliferation. ${ }^{19,29}$

The pathologic glomerular alterations observed agreed in general with previously published reports. ${ }^{19,20}$ During the first days after HSV injection, the massive loss of glomerular cells with few glomerular $\alpha$-SMA ${ }^{+}$cells provided evidence of mesangiolysis. Local inflammation was confirmed by the overexpression of MCP-1, RANTES, Cox-2, and IL-6, together with the infiltration of macrophages. Glomerular recovery on day 7 was preceded by glomerular cell proliferation $\left(\mathrm{Ki}-67^{+}\right.$cells) and accompanied by an increase in activated $\alpha-\mathrm{SMA}^{+}$mesangial cells. However, no glomerular hypercellularity was observed, perhaps because this study focused only on the first week after venom injection or because the pathology rapidly regressed in the $\mathrm{C} 57 \mathrm{Bl} / 6$ strain of mice. ${ }^{20}$ Mesangiolysis may be explained by the necrotic death of glomerular cells because of the acute lesion of mesangial matrix, as apoptotic cells were not observed in damaged glomeruli.

The major finding in this study was the expression of PTHrP in glomeruli immediately after HSV injection. Immunostaining showed the presence of PTHrP in all glomerular cells, including residual endothelial and mesangial cells, as well as podocytes. This staining was performed on washed kidney slices because an intense unspecific autofluorescence of erythrocytes hindered the correct visualization in unwashed kidneys. PTHrP overexpression was confirmed at the transcript level in glomeruli isolated from HSV-treated mice in unwashed kidney. It was restricted to the first days after HSV and was short lasting. This expression may involve all of the cells present in momento in the glomerular compartment, including infiltrating immune cells. There were not enough proteins in the isolated glomeruli to ascertain PTHrP overexpression by Western blot analysis. We and others previously documented that PTHrP can be expressed in activated mesangial cells in vivo and mesangial cells in culture, ${ }^{11,15,30}$ as well as in podocytes ${ }^{31}$ and endothelial cells. ${ }^{32}$ Infiltrating macrophages and T lymphocytes in HSV-damaged glomeruli may be another source of PTHrP, according to previous reports. ${ }^{33,34}$ In addition, it was found that HSV can directly induce PTHrP expression in mesangial cells in culture (M.H., unpublished results). The effect of HSV may also increase from the local inflammation. HSV has been shown to up-regulate IL- $1 \beta$ in macrophages, ${ }^{21}$ and IL-1 $\beta$ increased PTHrP expression in mesangial ${ }^{16}$ and endothelial cells. ${ }^{32}$ The PTHrP receptor, present on mesangial and endothelial cells as well as on podocytes, ${ }^{15,31,35}$ did not vary during the experiment on the mRNA level.

PTHrP has been shown to be overexpressed by many inflammatory factors ${ }^{14,36,37}$ and acts as a proinflammatory cytokine. It enhanced MCP-1, RANTES, and IL-6 expression in vitro in different types of cells. ${ }^{36-38}$ In vivo in a model of acute kidney injury by obstruction of urinary outflow, the expression of these cytokines/chemokines was amplified in mice overexpressing PTHrP in proximal tubular cells. ${ }^{37}$ We recently reported, in mesangial cells in primary culture, that PTHrP enhanced inflammatory mediators and increased Cox-2 expression together with its own expression by activating the NF- $\kappa$ B pathway. ${ }^{16}$ The present study shows that PTHrP acts similarly in vivo in HSV-induced glomerulonephritis. Indeed, treatment with the PTHrPneutralizing antibody reduced the expression of several inflammatory factors (ie, MCP-1, RANTES, Cox-2, and IL-6), blunted macrophage infiltration, and diminished PTHrP 
A

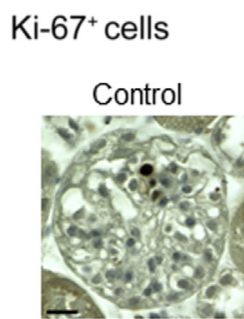

HSV

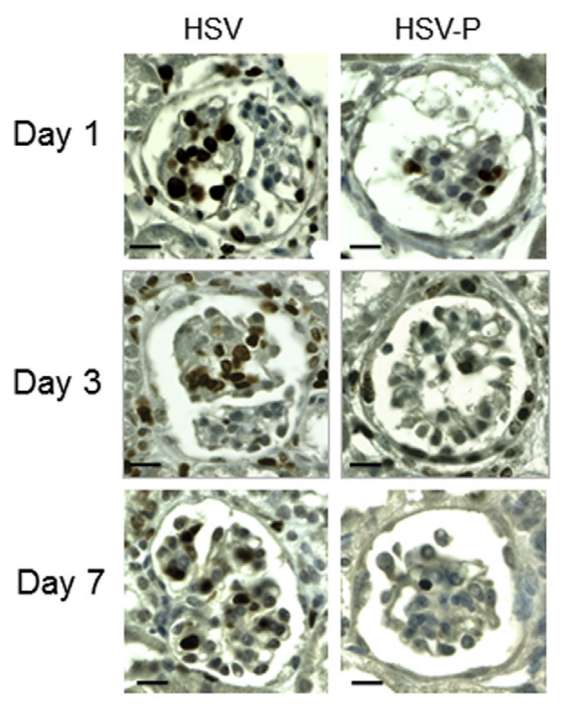

C
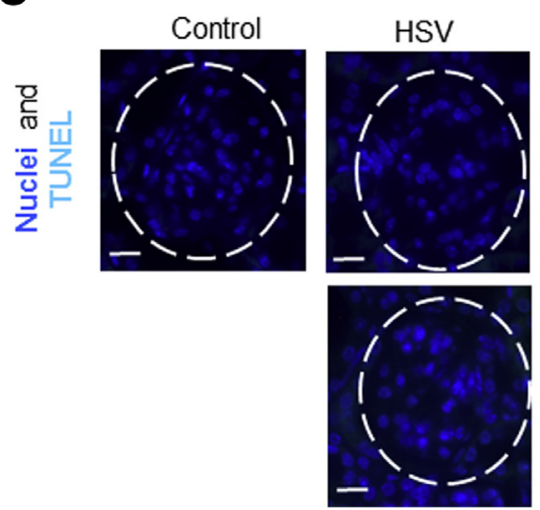

B
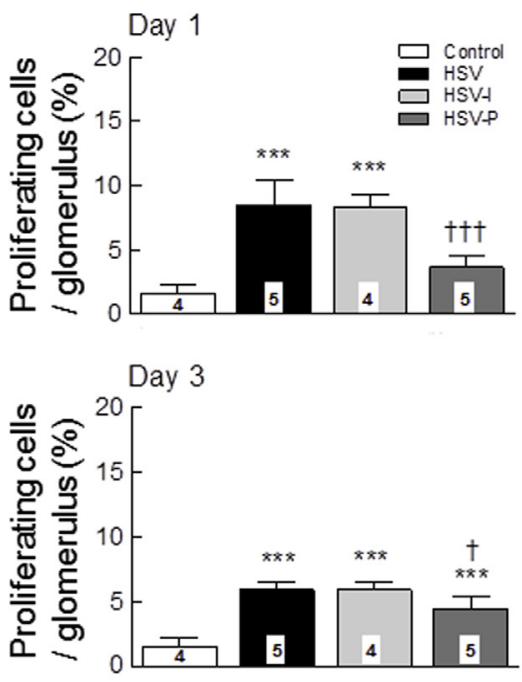

Day 7

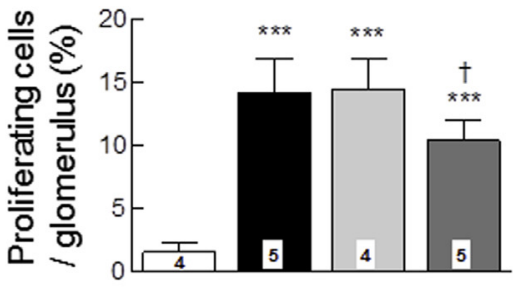

HSV-P

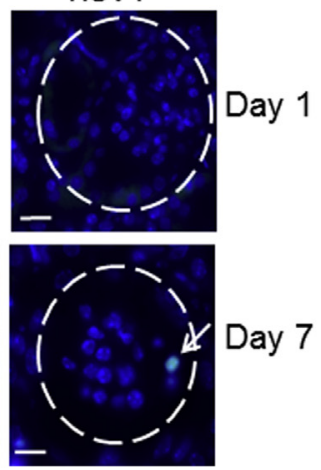

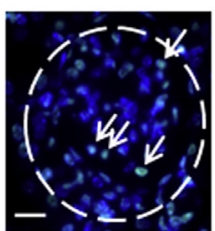

TUNEL positive control

Figure 8 Effects of HSV and of PTHrPneutralizing antibody (PTH2E11) on glomerular cell proliferation and apoptosis in mice. A: Representative immunostaining of $\mathrm{Ki}-67$ on washed kidneys. B: The number of glomerular proliferating cells (Ki- $67^{+}$cells) was determined on washed kidneys from the four experimental groups (control, HSV, HSV-I, or HSV-P; Materials and Methods). Results were expressed as percentage proliferating cells per glomerulus ( $n$ is indicated for each group). Statistical analysis by analysis of variance, followed by Tukey's test. C: Representative immunofluorescence staining of apoptotic cells [terminal deoxynucleotidyl transferase dUTP nick end labeling (TUNEL)] from washed kidneys. No apoptotic cells were observed in the HSV-treated group all over the study (data shown for day 1 and day 7). A positive control was included in the TUNEL assay, by treating the slides with recombinant DNase I $(1000 \mathrm{U} / \mathrm{mL} ; 10$ minutes at $20^{\circ} \mathrm{C}$ ). Dashed circles show the limits of glomeruli, and arrows indicate some apoptotic cells. Data are expressed as means \pm SEM (B). $* * * P<0.001$ versus control; ${ }^{\dagger} P<0.05$, ${ }^{\dagger \dagger \dagger} P<0.001$ versus HSV on the corresponding day. Scale bars $=10 \mu \mathrm{m}(\mathbf{A}$ and $\mathbf{C})$. Original magnification, $\times 650$ (A and $\mathbf{C})$.

expression in HSV-damaged glomeruli. The absence of PTHrP reduced the glomerular cell population without modifying PDGF expression, and increased the glomerular injury. Altogether, these results suggest that in response to the injury, PTHrP amplifies the glomerular inflammation, which itself helps to maintain a high local PTHrP secretion.

It has been suggested that an early expression of PDGF promotes mesangial cell growth and contributes to mesangial proliferation in $\mathrm{HSV}$-induced glomerulonephritis. ${ }^{19,39}$ In this study, the expression of PTHrP transcripts was observed with a kinetic similar to PDGF in glomeruli from HSV-treated mice, but with a higher level of up-regulation.
PTHrP is also a potent mitogen of mesangial cells, as we reported before. ${ }^{15}$ Using cells with PTHrP-gene excision and transfection with different PTHrP constructs, the results revealed that PTHrP enhanced mesangial cell proliferation only through an intracrine pathway, after translocation of the protein to the nucleus attributable to the presence of a bipartite nuclear localization sequence in its structure. Thus, both PTHrP and PDGF may act in concert and favor the glomerular repopulation. The role of PTHrP in this repopulation was evident in the present study because the neutralization of PTHrP in venom-treated mice hampered the glomerular restructuring, likely by reducing mesangial 
cell proliferation. Indeed, a part of PTHrP produced in mesangial cells in an inflammatory environment may reach the nucleus to be active through the intracrine pathway. Moreover, a lack in PTHrP makes mesangial cells more prone to apoptosis, as shown herein when exposed to HSV or before with tumor necrosis factor- $\alpha .{ }^{16}$ The present results indicate that PTHrP is beneficial to the glomeruli and appears essential for early glomerular repair in HSV-induced glomerulonephritis. No changes were observed in vascular endothelial growth factor transcript expression, which has been suggested previously as the key factor for endothelial recovery in this model. ${ }^{23}$ We have no explanation for this discrepancy.

Macrophages are major contributors to acute kidney injury. ${ }^{40}$ MCP-1 and RANTES promote monocyte recruitment, and IL-6 may play a role in macrophage differentiation. ${ }^{41}$ In the early phase, macrophages display a proinflammatory phenotype (classically activated M1 macrophages), characterized by the expression of inflammatory mediators (IL-1 $\beta$, IL-6, MCP-1, and inducible nitric oxide synthase-2), generation of reactive oxygen species, and tissue damage. Later on, when the renal microenvironment changes, macrophages switch to a noninflammatory phenotype (alternatively activated M2 phenotype) that expresses high levels of arginase-1 and promotes tissue healing. ${ }^{40}$ Lee et al ${ }^{42}$ reported, in a model of ischemic renal injury, that M1 macrophages were recruited during the first 2 days after injury, when M2 macrophages were present at later time points. A similar time course occurred in the nephrotoxic model, in which a short inflammatory phase (day 1 to day 3) with M1 macrophage recruitment was followed on day 7 by arginase-1-expressing M2 macrophages. At the same time, some increase in transforming growth factor- $\beta 1$ expression was observed, which is a marker of the presence of M2c macrophages. However, treatment with the PTHrP neutralizing antibody did not seem to affect the presence of M2 macrophages, thus excluding that the hampered healing process was linked to any indirect effect via the M2 macrophages. Although no fibrosis was observed during the short time of our study, a longer follow-up will be necessary to address this point.

In conclusion, PTHrP transcript expression and protein synthesis are up-regulated in damaged glomeruli after HSVinduced glomerulonephritis. The time course analysis showed that PTHrP up-regulation occurred in the early phase after HSV injection (day 1 to 3 ) and was coincident with an inflammatory environment. To evaluate the contribution of PTHrP in glomerular outcome, mice were treated with a PTHrP-neutralizing antibody. Our results show that PTHrP inactivation reduced the markers of local inflammation, largely reduced its own expression, hampered glomerular cell proliferation and survival, and finally prevented the healing process. Glomerular PTHrP overexpression seems, therefore, essential for early glomerular repair in HSV-induced glomerulonephritis.

\section{Acknowledgments}

We thank Dr. Mustapha Oulad-Abdelghani [Institut de Génétique et Biologie Moléculaire et Cellulaire (IGBMC)] for the generation of PTH2E11 antibody and Dr. Pedro Esbrit (Fundación Jiménez Díaz, Madrid, Spain) for the gift of $\mathrm{C} 13$ antibody.

M.H., D.R., C.C., C.B., S.D., A.B., and M.B. performed the research; M.H., C.C., and M.B. designed the study; T.M. contributed essential reagents; M.H., C.C., and M.B. analyzed the data; M.H., T.M., and M.B. wrote the article.

\section{References}

1. Philbrick WM, Wysolmerski JJ, Galbraith S, Holt E, Orloff JJ, Yang KH, Vasavada RC, Weir EC, Broadus AE, Stewart AF: Defining the roles of parathyroid hormone-related protein in normal physiology. Physiol Rev 1996, 76:127-173

2. Wysolmerski JJ: Parathyroid hormone-related protein: an update. J Clin Endocrinol Metab 2012, 97:2947-2956

3. Massfelder T, Dann P, Wu TL, Vasavada R, Helwig JJ, Stewart AF: Opposing mitogenic and anti-mitogenic actions of parathyroid hormone-related protein in vascular smooth muscle cells: a critical role for nuclear targeting. Proc Natl Acad Sci U S A 1997, 94: $13630-13635$

4. Henderson JE, Amizuka N, Warshawsky H, Biasotto D, Lanske BM, Goltzman D, Karaplis AC: Nucleolar localization of parathyroid hormone-related peptide enhances survival of chondrocytes under conditions that promote apoptotic cell death. Mol Cell Biol 1995, 15: 4064-4075

5. Agouni A, Sourbier C, Danilin S, Rothhut S, Lindner V, Jacqmin D, Helwig JJ, Lang H, Massfelder T: Parathyroid hormone-related protein induces cell survival in human renal cell carcinoma through the PI3K Akt pathway: evidence for a critical role for integrin-linked kinase and nuclear factor kappa B. Carcinogenesis 2007, 28:1893-1901

6. Massfelder T, Stewart AF, Helwig JJ: Parathyroid-hormone-related protein: a previously unrecognized renal vasodilator. Nephrol Dial Transplant 1995, 10:1984-1986

7. Clemens TL, Cormier S, Eichinger A, Endlich K, Fiaschi-Taesch N, Fischer E, Friedman PA, Karaplis AC, Massfelder T, Rossert J, Schluter KD, Silve C, Stewart AF, Takane K, Helwig JJ: Parathyroid hormone-related protein and its receptors: nuclear functions and roles in the renal and cardiovascular systems, the placental trophoblasts and the pancreatic islets. Br J Pharmacol 2001, 134:1113-1136

8. Raison D, Coquard C, Hochane M, Steger J, Massfelder T, Moulin B, Karaplis AC, Metzger D, Chambon P, Helwig JJ, Barthelmebs M: Knockdown of parathyroid hormone related protein in smooth muscle cells alters renal hemodynamics but not blood pressure. Am J Physiol Ren Physiol 2013, 305:F333-F342

9. Rizzoli R, Ferrari SL, Pizurki L, Caverzasio J, Bonjour JP: Actions of parathyroid hormone and parathyroid hormone-related protein. J Endocrinol Invest 1992, 15:51-56

10. Esbrit P, Egido J: The emerging role of parathyroid hormone-related protein as a renal regulating factor. Nephrol Dial Transplant 2000, 15:1109-1111

11. Izquierdo A, Lopez-Luna $\mathrm{P}$, Ortega A, Romero M, GuitierrezTarres MA, Arribas I, Alvarez MJ, Esbrit P, Bosch RJ: The parathyroid hormone-related protein system and diabetic nephropathy outcome in streptozotocin-induced diabetes. Kidney Int 2006, 69:2171-2177

12. Lorenzo O, Ruiz-Ortega M, Esbrit P, Ruperez M, Ortega A, Santos S, Blanco J, Ortega L, Egido J: Angiotensin II increases parathyroid hormone-related protein (PTHrP) and the type $1 \mathrm{PTH} / \mathrm{PTHrP}$ receptor in the kidney. J Am Soc Nephrol 2002, 13:1595-1607 
13. Ortega A, Ramila D, Izquierdo A, Gonzalez L, Barat A, Gazapo R, Bosch RJ, Esbrit P: Role of the renin-angiotensin system on the parathyroid hormone-related protein overexpression induced by nephrotoxic acute renal failure in the rat. J Am Soc Nephrol 2005, 16: 939-949

14. Funk JL: A role for parathyroid hormone-related protein in the pathogenesis of inflammatory/autoimmune diseases. Int Immunopharmacol 2001, 1:1101-1121

15. Hochane M, Raison D, Coquard C, Imhoff O, Massfelder T, Moulin B, Helwig JJ, Barthelmebs M: Parathyroid hormone-related protein is a mitogenic and a survival factor of mesangial cells from male mice: role of intracrine and paracrine pathways. Endocrinology 2013, 154: 853-864

16. Hochane M, Raison D, Coquard C, Béraud C, Bethry A, Danilin S, Massfelder T, Barthelmebs M: Parathyroid hormone-related protein modulates mice mesangial cells inflammation and blunts apoptosis by enhancing Cox-2 expression. Am J Physiol Cell Physiol 2018, 314: C242-C253

17. Morita T, Yamamoto T, Churg J: Mesangiolysis: an update. Am J Kidney Dis 1998, 31:559-573

18. Cattell V, Bradfield JW: Focal mesangial proliferative glomerulonephritis in the rat caused by habu snake venom: a morphologic study. Am J Pathol 1977, 87:511-524

19. Barnes JL, Abboud HE: Temporal expression of autocrine growth factors corresponds to morphological features of mesangial proliferation in Habu snake venom-induced glomerulonephritis. Am J Pathol 1993, 143:1366-1376

20. Nakao N, Hiraiwa N, Yoshiki A, Ike F, Kusakabe M: Tenascin-C promotes healing of Habu-snake venom-induced glomerulonephritis: studies in knockout congenic mice and in culture. Am J Pathol 1998, 152:1237-1245

21. Kubo A, Iwano M, Kobayashi Y, Kyoda Y, Isumi Y, Maruyama N, Samejima K, Dohi Y, Minamino N, Yonemasu K: In vitro effects of Habu snake venom on cultured mesangial cells. Nephron 2002, 92:665-672

22. Kitamura H, Sugisaki Y, Yamanaka N: Endothelial regeneration during the repair process following Habu-snake venom induced glomerular injury. Virchows Arch 1995, 427:195-204

23. Haas CS, Campean V, Kuhlmann A, Dimmler A, Reulbach U, Forster C, Aigner T, Acker T, Plate K, Amann K: Analysis of glomerular VEGF mRNA and protein expression in murine mesangioproliferative glomerulonephritis. Virchows Arch 2007, 450:81-92

24. Champy MF, Selloum M, Piard L, Zeitler V, Caradec C, Chambon P, Auwerx J: Mouse functional genomics requires standardization of mouse handling and housing conditions. Mamm Genome 2004, 15 : 768-783

25. Masuda S, Hayashi H, Araki S: Two vascular apoptosis-inducing proteins from snake venom are members of the metalloprotease/disintegrin family. Eur J Biochem 1998, 253:36-41

26. Uiker S, Kriz W: Structural analysis of the formation of glomerular microaneurysms in the Habu venom model. Virchows Arch 1995, 426: 281-293

27. Chijiwa T, Deshimaru M, Nobuhisa I, Nakai M, Ogawa T, Oda N, Nakashima K, Fukumaki Y, Shimohigashi Y, Hattori S, Ohno M: Regional evolution of venom-gland phospholipase A2 isoenzymes of
Trimeresurus flavoviridis snakes in the southwestern islands of Japan. Biochem J 2000, 347:491-499

28. Barnes JL, Hastings RR, De la Garza MA: Sequential expression of cellular fibronectin by platelets, macrophages, and mesangial cells in proliferative glomerulonephritis. Am J Pathol 1994, 145:585-597

29. Barnes JL, Hevey KA, Hastings RR, Bocanegra RA: Mesangial cell migration precedes proliferation in Habu snake venom-induced glomerular injury. Lab Invest 1994, 70:460-467

30. Ortega A, Romero M, Izquierdo A, Troyano N, Arce Y, Ardura JA, Arenas MI, Bover J, Esbrit P, Bosch RJ: Parathyroid hormone-related protein is a hypertrophy factor for human mesangial cells: implications for diabetic nephropathy. J Cell Physiol 2012, 227:1980-1987

31. Endlich N, Nobiling R, Kriz W, Endlich K: Expression and signaling of parathyroid hormone-related protein in cultured podocytes. Exp Nephrol 2001, 9:436-443

32. Ferguson JE 2nd, Seaner RM, Bruns DE, Bruns ME: Interleukin-1 beta and interleukin-4 increase parathyroid hormone-related protein secretion by human umbilical vein endothelial cells in culture. Am J Obstet Gynecol 1995, 173:448-455; discussion 455-456

33. Adachi N, Yamaguchi K, Miyake Y, Honda S, Nagasaki K, Akiyama Y, Adachi I, Abe K: Parathyroid hormone-related protein is a possible autocrine growth inhibitor for lymphocytes. Biochem Biophy Res Commun 1990, 166:1088-1094

34. Zeimer HJ, Greenaway TM, Slavin J, Hards DK, Zhou H, Doery JC, Hunter AN, Duffield A, Martin TJ, Grill V: Parathyroid-hormonerelated protein in sarcoidosis. Am J Pathol 1998, 152:17-21

35. Isales CM, Sumpio B, Bollag RJ, Zhong Q, Ding KH, Du W, Rodriguez-Commes J, Lopez R, Rosales OR, Gasalla-Herraiz J, McCarthy R, Barrett PQ: Functional parathyroid hormone receptors are present in an umbilical vein endothelial cell line. Am J Physiol Endocrinol Metab 2000, 279:E654-E662

36. Martin-Ventura JL, Ortego M, Esbrit P, Hernandez-Presa MA, Ortega L, Egido J: Possible role of parathyroid hormone-related protein as a proinflammatory cytokine in atherosclerosis. Stroke 2003, 34:1783-1789

37. Ramila D, Ardura JA, Esteban V, Ortega A, Ruiz-Ortega M, Bosch RJ, Esbrit P: Parathyroid hormone-related protein promotes inflammation in the kidney with an obstructed ureter. Kidney Int 2008, 73:835-847

38. Funk JL, Cordaro LA, Wei H, Benjamin JB, Yocum DE: Synovium as a source of increased amino-terminal parathyroid hormone-related protein expression in rheumatoid arthritis: a possible role for locally produced parathyroid hormone-related protein in the pathogenesis of rheumatoid arthritis. J Clin Invest 1998, 101:1362-1371

39. Iida H, Seifert R, Alpers CE, Gronwald RG, Phillips PE, Pritzl P, Gordon K, Gown AM, Ross R, Bowen-Pope DF: Platelet-derived growth factor (PDGF) and PDGF receptor are induced in mesangial proliferative nephritis in the rat. Proc Natl Acad Sci U S A 1991, 88: 6560-6564

40. Huen SC, Cantley LG: Macrophages in renal injury and repair. Annu Rev Physiol 2017, 79:449-469

41. Su H, Lei CT, Zhang C: Interleukin-6 signaling pathway and its role in kidney disease: an update. Front Immunol 2017, 8:405

42. Lee S, Huen S, Nishio H, Nishio S, Lee HK, Choi BS, Ruhrberg C, Cantley LG: Distinct macrophage phenotypes contribute to kidney injury and repair. J Am Soc Nephrol 2011, 22:317-326 